\title{
The Eleventh Commandment: Ethics of Hypocrisy
}

\author{
Dominic Umoh \\ Department of Religious and Cultural StudiesUniversity of Port Harcourt, Nigeria.
}

\begin{abstract}
Leading a morally authentic life is difficult, though not impossible. It entails choosing between what is convenient and what is right; opting for consistency and resisting compromise, knowing quite well that unmasking oneself, admitting the truth about one's life may be embarrassing, too humiliating and takes the greatest courage, but it pays off morally. Using a philosophical analytic method the paper exposes and condemns the ethical clumsiness, "unmanliness" and immaturity of an all-round life of pretext and thereby concluding that life is much more than a game. It takes an enormous amount of courage to tell the world "This is me. I am not proud of «myself» - in fact I am a bit embarrassed by «myself» - but this is the truth of who I am."
\end{abstract}

\section{Submitted Date 19 June $2013 \quad$ Accepted Date: 24 June 2013}

\section{Introduction}

The story below concerns a phenomenon which occurred in the seventies, but which is still fresh in people's memory because of its moral significance. Its news shocked the whole locality. I have decided to start off with this story because stories constitute the very ingredients from which African philosophy is extracted. Okoro (2004:50)

During an annual convention hosted by a certain church somewhere in southern Nigeria, the host pastor was caught stealing cassava from a farm close to the presbytery. The owner of the farm had set up a vigilante group to guard the farm against thieves. When they caught the pastor, they gave him a big machete cut on the head. With the wound the whole incident could not be concealed. Cassava theft makes no headline in Annangland where the phenomenon occurred. Cassava is a common poor person's staple food in the locality. All through history, thieves have been stealing foodstuffs and livestock from others. Each generation was left to decide how to deal with such thieves whenever they were caught. Sometimes, they were paraded nude around the village and markets with the stolen goods dangling down their necks. At other times, even thieves stealing mere foodstuffs were brutally murdered as was the case during the Nigerian/Biafran war. Umoh (2012:18).

Such, they said, was meant to deter. But the pastor's case was different. Everyone knew him for his gentleness and piety. But as the saying goes: all that glitters is not gold. The selves we disclose to the public do not always tarry with the selves that we really are. Hybels (2011) in his terse comment to the book Who are you when no one's looking remarks that "Who we are in public is not an accurate gauge of our character. Our true character is shown when we are alone and no one is looking." Who am I when I am not caught; when I can commit any havoc and go unnoticed? That appears to be the true me. But is there any time when no one is looking? According to Christianity there is none; for "God is always near me, hearing what I say; watching all my thoughts and deeds". Hence as Christians there is no time we are truly ourselves, for we cannot hide from the One for whom darkness is as clear as noonday. However, in the above story, the fact that a well respected clergyman was involved and the incident became divulged during a public gathering of about thirteen churches made all the difference. From every indication that appeared not to be the first time the pastor had stolen from the farm. But, that was the very first time He was caught.

Nowadays, being caught seems to constitute a sin or crime of its own category, attracting graver criticism than the misdeed itself. And that was what changed everything to the worst in the pastor's case. The churches were in total disarray, confusion, shock and utter disbelief; and the community too. The convention came to an abrupt end. A terrible gloom descended on the neighbourhood similar to an atmosphere after a funeral of a youngster. The eleventh commandment had been broken: Thou shall not be caught. You can steal, kill, kidnap, commit fornication, adultery and abortion; you can embezzle and be involved in witchcraft activities but all appears so normal if you have not been identified with your misdeeds. The commission of a crime is bad enough, but being caught seems worse and unpardonable. 


\section{The Decalogue}

For Christianity, the Decalogue constitutes a way of life. It is a guide to righteous living, expounding and extolling moral rectitude while abhorring moral turpitude. The Ten Commandments cover the entire spectrum of Christian relationship - between man and himself, man and his fellow humans and between man and his God.

Unfortunately, life in contemporary society seems to have approved the promulgation of an additional commandment, the eleventh. It is formulated to suit the convenience, whims and caprices of today's society and not any morality. The eleventh commandment is very simple, though it has altered enormously the age-old laws of Christian living. Here it is in its simplicity: "Thou shall not be caught." The eleventh commandment appears to overshadow the ten other traditional laws; in fact it seems to shelter man from the exigencies, 'burdens' and norms of Christian living and whatever laws of righteousness the Koran contains. It is on the eleventh commandment that is anchored the Ethics of covert behaviour or undiscovered self, the morality of mere externality. We want people to see us and evaluate us different from who we actually are and our actions for what they unfold about us. This is the backdrop of hypocrisy or pretext whose critical ethical evaluation is the preoccupation of this paper.

\section{Hypocrisy}

According to Oxford Advanced Learner's Dictionary, hypocrisy is a "behaviour in which somebody pretends to have moral standards or opinions that he does not actually have." It is a situation in which people say one thing and do another. Hypocrisy results when "people and institutions are falsely masquerading in ethical norms and values" they do not possess.

The word hypocrisy comes from the Greek ítókpıбı (hypokrisis), which means "jealous", "playacting", "acting out", "coward" or "dissembling". The word hypocrite is from the Greek word

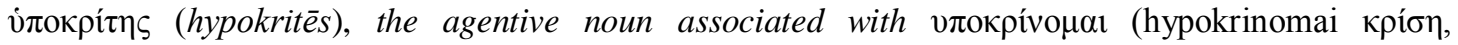

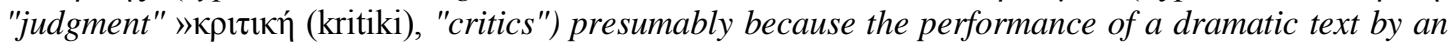
actor was to involve a degree of interpretation, or assessment. Alternatively, the word is an amalgam of the Greek prefix hypo-, meaning "under", and the verb krinein, meaning "to sift or decide". Thus the original meaning implied a deficiency in the ability to sift or decide. This deficiency, as it pertains to one's own beliefs and feelings, informs the word's contemporary meaning. en.wikipedia.org/wiki/hypocrisy.

From the above etymological definition, one thing comes out very clearly about the term. Hypocrisy is far from the authentic, the real, the genuine or the virtuous. Rather it involves stage-managing, play-acting, impersonating, pretending and above all falsification and deficiency. Hence in the past, 'hypocrite' was a technical term applied to public actors, stage performers and artists involved in rhetoric. Players of such roles were considered inapt for public offices especially in politics. For example in Athens in the 4th century BC the great orator Demosthenes ridiculed his rival Aeschines, who had been a successful actor before becoming involved in politics, as a hypocrite whose skill at impersonating characters on stage made him an untrustworthy politician. This negative view of the hypokrites, perhaps combined with the Roman disdain for actors, later shaded into the originally neutral hypokrisis. It is this later sense of hypokrisis as "play-acting", i.e., the assumption of a counterfeit 'persona' that gives the modern word hypocrisy its negative connotation. en.wikipedia.org/wiki/hypocrisy

Therefore J. Powell is right when he describes hypocrisy as "what is revealed when one has "scratched beneath the surface of empty rhetoric." Accordingly what goes for hypocrisy is the concealing of the unpleasant side of one's life; what lies consciously covered up from public view and criticism inside the manipulator. It is associated with the "self-righteous" and "self-appointed" who masquerade as "moral gurus" (Igram et al 88). Hypocrisy is an ethical con-game similar to the religious con-game warned against by Karl Marx. It is "the state of promoting or administering virtues, moral or religious beliefs, principles, etc., that one does not actually possess and that one is also guilty of violating. Hypocrisy often involves the deception of others and thus can be considered a kind of lie. It is simply failing to practice those virtues that one preaches." en.wikipedia.org/wiki/hypocrisy. Hypocrisy is a deceit or a pretext concerning one's lifestyle. Powell calls it the "scars and the defenses, which we use to protect ourselves from further vulnerability, (which) tend to form patterns of action and reaction. These patterns eventually become so self-deceptive that we forfeit all sense of identity and integrity. We act "roles," wear "masks," and play "games." (Powell 13).

Powell (1969:14) equally makes this all-important point concerning the origin of hypocritical tendencies in us when he notes that in reality none of us wants to be a fraud or to live a lie; none of us wants to be a sham, a phony, but the fears that we experience and the risks that honest self communication would involve seem so intense to us that seeking refuge in our roles, masks, and games becomes an almost natural reflex action. After a while, it may even be quite difficult for us to distinguish between what we really are, at any given 
moment in our development as persons, and what we pose as being. It is such a universally human problem that we might justifiably call it "the human condition."

In our society today we have placed a great stress on being authentic. We have talked about placing masks over the face of our "real" selves, and of playing roles which disguise our true and real selves. The implication is that somewhere, inside of you and inside of me, lurk our real selves....There are moments when this real self of mine shines out of me, and there are other moments when I feel compelled to camouflage my real self. Powell (7-8).

\section{Are we then all Hypocrites?}

We are all persons or personalities. Etymologically "personality' is derived from the Greek "Persona", a term dating back to $100 \mathrm{BC}$, denoting the Greek theatrical mask. According to legend, the mask was introduced to conceal the wearer's squint. Later on the word 'personality' was used to refer to the masquerader himself. In the latest sense it meant the masquerader producing sound from behind his mask. By the above etymology, it would seem we are all by nature 'hypocrites', because we all operate behind masks. That appears to be the implication of the above "human condition" or "almost natural reflex" of Powell. And as I have noted elsewhere:

Personality, according to this dispensation would be the person as he shows himself to be, not as he really is. This conception is well grounded in the modern English word impersonate, which means to "act the part of", "to pretend to be." Very often in our day to day existence, we wear this 'conventional mask' by hiding from the critical world, our true selves - our proper identity. Thus we go about parading other selves which are far from our real selves (Umoh 2009:24).

I have observed in this regard that putting on this "mask of collective minds" or "of disguised individuals" is quite natural and in fact inescapable. From this objective, 'we are all naturally hypocrites.' Sheltering ourselves from the critical world has become a natural game we all play. We all try to dance to the tune of the society in which we find ourselves by concealing a part of our true identity and covering up some of our actions considered defective. And Powell is right in arguing that:

It is doubtful that there is anyone who does not play these or other games. Therefore, if I really want to "see it like it is... and tell it like it is," I must ask myself some difficult questions about the patterns of action and reaction that emerge in my conduct, and I must ask myself what these patterns reveal to me about myself." (p.26).

There is nobody on earth who can open up to the public or even to his/her most cherished life partner so completely to the point of having nothing to hide. He would lose his personal identity in the process. Any personality who 'has nothing to hide' from the public even unconsciously or at least by way of mental reservation, is insane. This is confirmed by the following statement of Fagothey $(1977: 267)$ namely that the natural law gives man a right to his own personal dignity and independence, to freedom from meddling and prying into his private affairs. To preserve this right the concealment of the truth is often necessary. As he continues, "outspoken telling of the unvarnished truth on every occasion would lose us all our friends and make us unfit for society. But as we will see in a while, real hypocrisy, which is the topic of this paper is far beyond this 'natural pretext'. Umoh (2011:103) has made recourse to these "allowable" or "white lies" in the following lines:

What is important to us here is the fidelity of the term 'person' to its etymological root, because ...human beings - persons - do not only sound through the mask, they do everything behind the mask. This makes the reality behind the mask a very ambiguous one, a very complicated one, a very elusive one and the activities going on behind the mask incomprehensible. Hence the entity behind the mask is very difficult to grasp, to understand, to predict, to categorize. It is slippery.

The external 'persons' we carry about, that we are, that we display to the public, are far from being all that we are. They do not tell the whole story about us. They do not and cannot portray everything of us. They do not exhaust 'us'. Very often they are everything short of our 'true and authentic' selves. It is all these that sometimes metamorphose into real hypocrisy because "most of us feel that others will not tolerate such emotional honesty in communication. We would rather defend our dishonesty on the grounds that it might hurt others; and, having rationalized our phoniness into nobility, we settle for superficial relationships." (Powell 88).

\section{Hypocrisy in Moral Perspective}

From the ethical point of view, hypocrisy that has come to stay as the new order in today's in our society is at variance with morality. Having the society's approval for every bit of one's camouflaged lifestyle is purely immoral. It is a well established principle in ethics that morality is not legality. That means that what the 
community approves or recommends even legally is not always moral. Put otherwise, sociality or legality is not morality. Rather what obtains in society must be judged, evaluated, appraised, approved or disproved against the backdrop of ethical principles in order to establish their moral worthiness and tenability. Hypocrisy is therefore a confused and a misplaced value. The immoral character of hypocrisy is what Jesus condemns in this biblical texts directed against the scribes and the Pharisees: "They preach, but do not practice." (Matt. 23: 3).

Woe to you scribes and Pharisees, hypocrites! for you cleanse the outside of the cup and of the plate, but inside they are full of extortion and rapacity." (Matt. 23:25). Woe to you scribes and Pharisees, hypocrites! for you are like whitewashed tombs, which outwardly appear beautiful, but within they are full of dead men's bones and all uncleanness. So you also outwardly appear righteous to men, but within you are full of hypocrisy and iniquity (Matt. 23: 25-28).

The entire biblical text above contrasts the pure outward show of the scribes and Pharisees with sincere moral qualities that belong to the essential nature within the individual. Elsewhere Jesus criticizes the Pharisees for dressing obsequiously and praying at market places and street corners, in order to attract attention.

From the viewpoint of professional ethics, which is all about the moral integrity in the areas of one's profession hypocrisy is, to say the least, a moral depravity. It involves the very opposite of what virtues stand for; it mars qualities like humility, sincerity and honesty; it impugns our integrity, brings disrepute to or tarnishes the image of professionals. Hypocrisy promotes fake professionalism, moral indifference and cynicism. The greatest problem facing Nigeria today, corruption, stems from this lack of moral integrity and genuineness in the government and bussiness.

Hypocrisy is corruption, perversity, cowardice, fallaciousness, debasement, and a compromise to moral wholesomeness. In academics for instance, it breeds examination malpractices, cultism, sale of degrees and sorting results, forgery, alteration of records, embezzlement. In government it cripples the economy and enhances bad governance. Hypocrisy is a serious setback to taking people seriously; it hampers people accepting what others say at first value and it breeds a trustless society. The society is entitled to a certain amount of truth about us which is denied by pretext which is lies personified. That is why Ingram et al affirm that wherever hypocrisy reigns: "Our trust is shaken, when words and actions don't quite match up. What we observe doesn't match what others tell us and even what we tell ourselves!" Ingram and Parks (2002: 88). And according to Fagothey (261), "Lying seems to have its own peculiar malice distinct from its effects, from the lack of justice or charity by which the other's right (to know the truth) is violated"

In more concrete circumstances, why do our pregnant teenage girls opt for abortion in case of unwanted pregnancy instead of keeping the baby? Is it not in order to brandish other selves (the virgins that they no longer are) to the society, preferring what is convenient to what is ethically right? This is playing game with the society - a purely vicious life pretending to be virtuous. Pre-marital as well as extra-marital sex can never be admitted publicly by those indulged in them as that would tarnish their images. And so they showcase other selves - the false ones - to the society. Such a life is deceitful and impersonating and therefore ethically ignoble. Hypocrites are too busy playing life's little games to actually have the time to stand back and cast a critical glance at their actions and lives. But life is more than a game. Why do criminals like kidnappers, armedbandits and hired assassins wear masks, if not to camouflage their true and ignoble identities? Politicians and business tycoons duping state treasuries by embezzling or tax evaders who do their utmost best to appear lawabiding and honest citizens in the eyes of the public unless they are tracked down or netted are operating under the guise of hypocrisy. Even here in Nigeria the United States sponsored free HIV/AIDS tests meant for the discovery of individuals' HIV status is suffering setbacks for the same reasons. This is because people are ashamed of being discovered HIV positive, so they refuse to undergo the test. It is true that such might sometimes breed discrimination and humiliation. Hence they would rather prefer remaining ignorant of their true status and dying in their ignorance to 'betraying' themselves to the public. Such is the implication of this remark by Powell:

I am afraid to tell you who I am, because, if I tell you who I am, you may not like who I am, and it's all that I have... (this is) the imprisoning fears and self-doubt which cripple most of us and keep us from forward movement on the road to maturity, happiness, and true love. (p. 12)

If one considers the Boko Haram terrorist group in Nigeria, this same tendency is in vogue. Politicians in the very heart of the Nigerian government are the real terrorists wearing the masks of Boko Haram. They do so using good-for-nothing refracts, paying them heavily to terrorize the public. In the government they pretend to be well-meaning Nigerian politicians, but behind the screen they are the real destructive agents of the very government which they are claiming to serve.

This type of insincerity is what Augustine referred to as "the darkness deep within myself, a darkness I am reluctant to admit.... though God is saying to me, "This too is part of you. You are not as perfect as you sometimes pretend to be." (Burt: 14). Hence when we are playing the game of life, we scarcely have any time to step outside the game and question its ground rules. We never have time to watch our styles critically and 
thereby come to grip with our pitfalls. That is why being a spectator can sometimes be more rewarding than playing the game. However, 'the trick is being able to do both at the same time!' (Ingram et al 89).

In addition to the above, hypocrisy involves self-estrangement and self-deception. This is the point Ejizu is making here referring to a dual commitment of some apparently good Christians who nonetheless constantly compromise their Christian allegiance by serving other gods. Openly they are wonderful church members while very faithful to fetishism in secret:

Thousands come to our churches. Our cathedrals and chapels are filled to capacity every Sunday and during important celebrations like harvest and bazaars. A lot of people also make huge donations for the upkeep of the church. Still many also avail themselves of the Sacraments.... But often, there are reports that practicing Christians are equally idol worshippers. They swear on idols, erect hidden shrines in their homes. They hide fetishes in their shades in the market stalls and in their workshops. Catechists, Seminarians on apostolic work in the towns and villages are stunned at the degree of idol worship and superstitious practices that still exist among a people that are mostly baptized Catholics. www.afrikaworld.net/afre/conversion.htm

This is purely syncretistic and pharisaic. And as Ehusani (1991) has also observed, Christian faith in Africa has suffered a terrible ambivalence in the hand of such insincere worshippers. This is because the external religious observances of some Christians do not match the disparate deeply rooted traditional beliefs of typical Africans.

Majority of African Christians live ambivalent spiritual lives; with an exterior allegiance to the God of Jesus Christ, but with an interior and perhaps a more profound allegiance to the God of their forbears who has refused to give way to the new God. There is a wide gap, a split, or is it a dislocation, of many Africans recently converted to Christianity, and this phenomenon cries out for attention. So soon after the "implanting" of Christianity in Africa, and just as the foreign missionaries are arriving home and congratulating themselves on the success of their proselytizing missions, "the love of many has gone cold." (159).

Some people call it syncretism, but it may be more like a dual religious allegiance, where Christianity is practiced in the daytime and occult practice is done at night. Many of the pastors will preach from the pulpit that this type of thing is wrong, but secretly take part in it at night. "There is the mentality, especially in African Initiated Churches, where the prosperity gospel is preached, that you do what you've got to do to get ahead. You rely on the powers available to you. You are hopeful that Christ will help, but when he can't come through on Sunday, you may take out a different insurance policy at night." frjody.com/tag/superstition

\section{Conclusion and Proposals}

We have just completed our brief trajectory exploring that phenomenon which is the closest to me, the cavern of my very self. It was the appreciation of the self that opened up to the ethical evaluation of hypocrisy and in the process many things have been laid bare about the lifestyle of the contemporary man. The society today is discovered to be the type that adopts a camouflaged type of existence as a way of life and this is dealing a serious blow on morality as far as authentic ethical existence is concerned. As we know, reputation is not rectitude; neither is prestige equitable with character. One is on a purely external and empirical point of view, while the other belongs to the very essence of the individual. Unfortunately, hypocrisy has sacrificed the latter on the altar of the former. By allowing the "Eleventh Commandment" to take over the entire scene of moral life, the contemporary man is opting for the non-essentials; for the superficial. Once the community can be deceived to accept me for what I am not, everything seems alright.

Suggesting ways out of the self-estrangement of hypocrisy, proposing means of liberating ourselves from this moral mayhem, may not be easy to come by and more so it may appear sermonizing. However, psychologists over the ages have always insisted on the benefit of courageous self evaluation and self acceptance. Spiritual directors have always insisted on the benefit of interiority noting that "there is no fixed, true and real person inside of you or me, precisely because being a person necessarily implies becoming a person, being in process. "If I am anything as a person, it is what I think, judge, feel, value, honor, esteem, love, hate, fear, desire, hope for, believe in and am committed to." (Powell: 8). Hence, it takes all amount of courage first of all to accept ourselves as we are; that is with all our discovered shortcomings. That is the beginning of the process of any self-authentication. We ought to be aware that we are not finished products already labeled "morally good" or "morally bad" by the community. According to Powell, my person is not a little hard core inside of me, a little fully-formed statue that is real and authentic, permanent and fixed; person rather implies a dynamic process. In other words, if you knew me yesterday, please do not imagine that it must be the very same person that you are meeting today. Man is not a pre-structured organism. We are and remain always wayfarers in view of our moral self-authentication, amelioration and development. Hence we should always discard shying away from unnecessary shame and fright. These are the human scars, inner fears and pains which block the avenue to true self-communication thereby converting life into a little game of always seeking public endorsement of our distorted lifestyle at all cost. It should now be clear that I am equally an interior being and 
interiority implies self-acceptance. This desired interiority means that this fully functioning, self-actualizing, fully human person is not only aware of physical, psychological and spiritual hungers and activities, but he accepts them as good. He is at home with his body, his tender as well as hostile emotions, his impulses, thought and desires. These are the things that define the person, and they are perpetually changing.

"Interiority" implies that a person has explored himself and has experienced himself. He is aware of the vitality of his senses, emotions, mind and will, and he is neither a stranger to, nor afraid of, the activities of his body and emotions. His senses bring him both beauty and pain, and he refuses neither. He is capable of the whole human gamut of emotions; from grief to tenderness. His mind is alive and searching; his will reaches out for an ever greater possession of all that is good and at the same time savors that which is already in his possession. He has listened to himself, and he knows that nothing which he hears is evil or frightening." (Powell: 31)

Such self-discovery may appear humiliating and letting it out to the public shameful; facing it is always difficult and exhausting because in order to reveal myself to myself I must first of all overcome myself. This is not a battle easily won. (Burt: 14). Therefore, the fully human person must strike a balance between "interiority" and "exteriority", for man is both. This is what is referred to as integration of personality. That is already an antidote to hypocrisy.

Therefore both the extreme introvert and the extreme extrovert attitudes are off balance and should be avoided. The introvert is almost exclusively concerned with himself; he becomes the center of gravity in his own universe. Because of his total concern with self, he is distracted from the vast world outside. The extreme extrovert, on the other hand pours himself out, moves from one external distraction to another. His life is not reflective at all, and consequently there is little interior deepening. (Powell 30). In the nutshell, all it takes is trying to be honest to oneself. It may be difficult, but never impossible. As Burt reflecting on St. Augustine's prayers observes:

If I cannot live with the truth about myself, I can never hope to discover the truth about God. Unless I am able to find the true "me", I will have nothing of value to offer others for them to love. Without some honest discovery of myself, there will be no "me" to be loved. I will be an empty shell of no importance." (15).

This type of self-acceptance ultimately leads to an empowerment. It becomes living confidently with all that goes on within us. It makes us afraid and shy of nothing that is a part of us. It discards defensiveness that engenders pretext; that is those things that imprison the self in its preconceived structural prejudices, making its world not larger than himself and the circle of his enclosed horizons. This confirms the age-old adage that anyone wrapped up in himself/herself makes a very small parcel.

\section{Works Cited}

[1]. Burt D. X. (2009) "Let me know Myself..." Reflections on the Prayers of Augustine (Mumbai: St. Pauls).

[2]. Ehusani G. (1991) "Christian Commitment: "The African Dilemma" African Dlemma: A Cry for Life, Kubi K. et al Eds. A collection of papers presented at Ecumenical Association of Third World Theologians (Eatwot) 159-166.

[3]. Fagothey A. (1972) Right and Reason: Ethics in Theory and Practice (St. Louis: Mosby).

[4]. Hybels B. (2011) Who are You when no one's Looking. Choosing Consistency, resisting Compromise. (Mumbai: St. Pauls).

[5]. Ingram D. and Parks J. (2002) The complete Idiot's Guide to Understanding Ethics (U.S.A. Alpha)

[6]. Okoro, C. (2004) "Problems in definition of Meaning, Nature and Scope of African Philosophy" in WAJOPS West African Journal of Philosophical Studies, Vol. 7, 2004, (48-63).

[7]. Powell, J. (1969) Why am I afraid to tell you who I am? (Chicago: Argus communications).

[8]. Umoh D. (2009) A Philosopher looks at Annang Personality, its characterizing Traits, Development and Features (Enugu: Snaap Press).

[9]. Umoh D. (2011) “The Reality behind the Mask in «Ekpo Ikpaisong» in Annang Culture of Akwa Ibom State, Nigeria” Journal of Communication \& Culture, Vol. 2, No. 1, 101-108.

[10]. Umoh D. (2012) Memories of the Nigerian Civil War. An Ethico-Religious Hermeneutics. (Port Harcourt: University of Port Harcourt Press).

[11]. Wehmeier S. (2005) Oxford Advanced Learner's Dictionary (Oxford: Oxford University).

[12]. en.wikipedia.org/wiki/hypocrisy

[13]. www.afrikaworld.net/afre/conversion.htm

[14]. frjody.com/tag/superstition 